\title{
EHMTI-0210. Dolotest may reflect the effect of psychological treatment in patients suffering from severe headache
}

\author{
T Zimmer*, CB Møller, ML Westergaard, D Kjeldgaard Nielsen \\ From 4th European Headache and Migraine Trust International Congress: EHMTIC 2014 \\ Copenhagen, Denmark. 18-21 September 2014
}

\section{Introduction}

Patients with severe headache who undergo psychological treatment at the Danish Headache Center, a tertiary multidisciplinary treatment centre, often report positive effects on their perceived general well-being and ability to work. However there is no agreement on which quality of life (QoL) instruments are useful for monitoring outcome of psychological treatment.

\section{Aim}

To assess the effect of psychological treatment in headache patients using the DOLOtest, a newer validated Health-Related QoL instrument.

\section{Method}

All patients referred to psychological assessment at the Danish Headache Center in 2012 underwent an initial interview and 129 were offered psychological treatment. Treatment was either group treatment or individual therapy. All participants were given the DOLOtest, at baseline, 1 st, 5 th and last therapy session and at six-month followup. DOLOtest-scores were compared using t-test.

\section{Results}

Of the patients offered treatment, 100 accepted, 93 completed, and 71 were reached at six-month follow-up. There was a significant improvement on the following domains at six-month follow-up compared to baseline: pain $(\mathrm{p}=.039)$, problems with more strenuous physical activities $(\mathrm{p}=$ .037), reduced energy and strength $(\mathrm{p}<.001)$, and low spirit $(\mathrm{p}=.007)$. Headache frequency was also significantly reduced from 23 to 17 days/month $(\mathrm{p}<.001)$.

Department of Neurology, Danish Headache Center University of Copenhagen, Glostrup, Denmark

(c) 2014 Zimmer et al; licensee Springer. This is an Open Access article distributed under the terms of the Creative Commons Attribution License (http://creativecommons.org/licenses/by/2.0), which permits unrestricted use, distribution, and reproduction in any medium, provided the original work is properly cited.

\section{Conclusion}

The DOLOtest may be a valuable multidimensional instrument to assess QoL in patients with severe headache, and to monitor outcome of psychological treatment in future trials.

No conflict of interest.

Published: 18 September 2014

doi:10.1186/1129-2377-15-S1-D34

Cite this article as: Zimmer et al:: EHMTI-0210. Dolotest may reflect the effect of psychological treatment in patients suffering from severe headache. The Journal of Headache and Pain 2014 15(Suppl 1):D34.
Submit your manuscript to a SpringerOpen ${ }^{\circ}$ journal and benefit from:

- Convenient online submission

- Rigorous peer review

- Immediate publication on acceptance

- Open access: articles freely available online

- High visibility within the field

- Retaining the copyright to your article

Submit your next manuscript at $\mathbf{s p r i n g e r o p e n . c o m ~}$ 